\title{
Robin Horton of the Niger Delta
}

It is my sad duty to announce the death of a great colleague, Professor Robin Horton, at age eighty-seven. He died of diabetes.

According to his son, Chief Dr Godwin Douglas, he died peacefully on 28 November at 4 p.m. His funeral was planned for mid-January 2020.

His passing has been formally reported to His Majesty the King of the Kalabari at Buguma where Robin has lived as a respected citizen and elder member of the Ekine Society.

The King, himself a former professor at the University of Port Harcourt, has approved that Robin be interred in the special cemetery in the city reserved for royalty, rather than in the common community cemetery across the river.

Robin fell in love with the Niger Delta from his first visit as a graduate research student in search of bronze artifacts across the region. He abandoned all interest in further degrees and settled down to live and work in the Niger Delta to the end of his life.

He had an engaging and funny way of reporting his field experiences. On that first trip, he met King Ben Wari of Bassambiri, Nembe, who had attended public school in England in his youth, with little to show in formal educational value. The King asked after his childhood friends in public school, various lords and political figures.

When Robin failed to show any personal knowledge of such aristocrats, the King ordered him to, virtually, 'Get lost' - 'Bogoroff.' Such fun-making with revered personalities sometimes got Robin in trouble as a person with no respect for revered leaders.

However, I came to realize that such inferences were not well founded. He also made fun of his own father, who made the money with which he was able to pursue his single-minded Niger Delta research and writing. He joked that money had not achieved his full entry into British aristocratic circles. He was also careless about hallowed traditions regarding appearance to lecture at the University of Oxford and other places operating stiff-necked traditions and formalities.

I am convinced that Robin's love for the Niger Delta was genuine and cerebral. His first Kalabari wife, who lost her life and child in childbirth, gave him an artist daughter, Sokari Douglas Camp, now a celebrity in the United Kingdom. Chief Dr Douglas who is taking care of Robin's current Kalabari family has proved a reliable son.

The deepest and strongest attachment Robin had to the Niger Delta lay in his work among the Kalabari, in particular as a member of the Ekine Society of Buguma. He spoke fluent and idiomatic Kalabari. He knew the drum language and told me about recordings of ancient sagas, folklore and community histories.

His writing is replete with evidence of a more than ordinary understanding of Kalabari-Ijo culture and tradition. I remember one proverbial statement he cited in describing the Kalabari attitude to the gods and spirituality: 'If a god became arrogant, the people would tell it the tree out of which its figure was sculpted.' In the mode of this adage, Robin was fascinated with Kalabari-Ijo 
culture, but with a light-hearted frame of mind, ready to discard old gods for new gods or none.

Robin's attachment to the Ekine Society of Buguma was such that for the many decades he had been a member he hardly missed any performance. If he went on vacation to the United Kingdom and heard of a planned performance in Buguma, he took the next flight to be present at the show.

The result is that at the point of his death Robin was one of the most revered authorities on Kalabari Ekine traditions in Buguma.

We may note that Robin makes the third case of expatriate scholars who have been buried in the Niger Delta: namely, following C. B. Powell, the environmental scholar from Canada, and the linguist, Kay Williamson of the United Kingdom.

For these scholars, the Niger Delta was an attractive cultural environment. They lived to tell a positive story out of the Niger Delta. They are now a part of the history of the Niger Delta.

Robin has the distinction of leaving a blood line in young Winnie Robin Horton in the Douglas family of Kalabari.

Ebiegberi Joe Alagoa

Ebiegberi Joe Alagoa is Professor Emeritus at the University of Port Harcourt, Port Harcourt, Nigeria. 